\title{
The Holding Company as an Instrument of Companies' Tax-Financial Policy Formation
}

\author{
Dominik Gajewski ${ }^{1}$
}

\begin{abstract}
The aim of this article is to present the holding institution as an economic and taxation solution. This article describes the holding company, indicates its advantages and disadvantages, and compares it to similar solutions. The main goal of holding companies is to change tax policies. As a result of these institutions, companies can change their tax status and economic situation. The holding institution influences the economic development of its constituent companies. The functioning of a holding company also has great importance for economic development. Establishing holdings is a worldwide trend that may be realised through various models.
\end{abstract}

KEY WORDS: $\quad$ holding company, income tax from legal persons, capital company

JEL Classification: $\quad \mathrm{H} 21, \mathrm{H} 25$

1 University of Finance and Management in Warsaw, Poland

\section{Introduction}

In the Polish economy, increased activity of holding companies is becoming common. The growing number of companies in the Polish economy has resulted in more intensive connections between these companies. This type of relationship has led companies to form groups of holding companies. .

According to Froud, Haslam, Johal and Williams (2000), mainstream economics pays disproportionate attention to these large private economic organisations given their importance in the modern economy. Their economic and tax aspects increase the attractiveness of these institutions (Poterba 2004).

Correspondence concerning this article should be addressed to: Dominik Gajewski, University of Finance and Management in Warsaw, 55 Pawia Str., 01-030 Warsaw, Poland, e-mail: d.gajewski@op.pl

\section{Holding as a financial instrument}

In the era of globalisation, holding companies have become a popular and advantageous way of doing business. Their numerous benefits have motivated many businesses to direct their strategy towards creating holding structures.

Capital companies operating in the fields of production or exchange attempt to achieve their goals through numerous direct and indirect relationships with other companies (Lichtarski, 1992). Companies' forms of cooperation can be divided into two basic groups: cooperation and concentration.

The main objectives of the consolidation of cooperative entities are to maintain the legal personalities of interacting entities through voluntary and reversible interaction. Another important objective is to maintain the entities' economic independence as expressed through the typical qualities of autonomous enter- 
prises, such as immutable ownership, lack of central leadership and freedom in the selection of executives (Overesch, Wamser, 2010).

Cooperation that takes the form of concentration is characterised by the establishment of a common leadership for the cooperating entities. Furthermore, the entities' loss of economic independence when subordinated to the general management is assessed. An important feature of the concentration form is the potential, in certain conditions, for the loss of legal personality for at least some of the entities (full fusion) (Bestmann, 200; Wöhe, 1978).

A market economy based on cooperation between companies, regardless of their legal status, is a cooperative form. A growing economy also involves the concentration form of cooperation. According to Palpaceur (2008), this is directly related to the fact that the growing interest of institutional investors and banks is reflected in the establishment of large corporations.

\section{The concept of holding}

The concept of holding has no statutory definition. The definition of a holding company is based mainly on economics and laws. It can be difficult to define precisely because there is no consensus on the notion of holding. Holding institutions will be perceived differently by an economist, a specialist in management or a lawyer.

Some consider a holding company a company that holds shares of other companies in amounts sufficient to influence the decisions of these companies (Solarz, 1992). Others consider a holding company one that is controlled by another entity, regardless of the method of control (Warchol, 2001). However, the predominant view sees a holding company as a group of companies with the ability to impose its will by holding sufficient shares (stock) in one company (Kubot, 1993; Stecki, 1999; Nogalski \& Ronkowski, 1994).

In terms of the foreign doctrines and economic practices in the use of this type of institution, a holding company can be defined as a structure consisting of at least two legally independent economic entities, one of which is in a position to influence the decisions made by the other entity as a result of an agreement between these entities concerning the acquisition of the capital share of one entity (the subsidiary) by the other entity (the dominant). This agreement is called the holding agreement.
The concept of holding is an interdisciplinary notion (Szumański, 1996; Vlachy, 2008) that has not been defined in any legal system in the world. Such attempts have been made only by the representatives of the doctrine. Attempts to define the notion of holding largely depend on whether it is to be considered in terms of economic, tax or legal aspects. Language and methodological differences exist between these disciplines (Karolak, 2001).

In a legal sense, holding means the capital connections that allow a parent company to influence the activities of a subsidiary by forcing its decisions in a general meeting and influencing the staffing of the subsidiary (Szumański, 1996). An important feature of holding that distinguishes it from similar forms is the fact that the parent company does not run the business itself; it only holds shares in subsidiaries and uses its rights on these grounds (e.g., in international tax treaties, the reduction or even exemption from tax on dividends paid in the source country) (Kessler, 1996). A characteristic feature is the holding of shares (stocks) or, more broadly, capital relations between parent and subsidiary companies (Stecki, 1999).

There are three criteria to determine whether a structure is ranked as a holding company:

1. preparation of the consolidated balance sheet, which includes an account of the financial results of the parent and subsidiary companies (in Polish law, the Act of September 29, 1994 on Accounting and the Law of February 15, 1992 on Income Tax from legal persons introduced the possibility of a consolidated balance sheet for capital groups);

2. possession of the majority of votes at the general meeting of shareholders;

3. the ratio of the relationship to the company management, which is dependent on the decision of the parent entity.

It is also worth noting the difference between a holding company and the concern, which is often identified with the holding. The concept of concern includes the clusters of companies in which the dominant entity (the parent company) and its subsidiaries conduct business and specify the strategy for the entire group. A significant notion is unified management. Joint entities with legal and economic constraints within the group maintain independent legal personalities (Stecki, 2001). 

sion are the theories of taxation of holding companies. The largest is the group of countries that base their tax arrangements on the theory of economic unity: the Netherlands, Spain, Portugal, France, Great Britain and Ireland. Their tax regulations meet all the criteria necessary to treat the holding as economic unity.

According to the theory of unity, a holding company does not have tax subjectivity. A holding becomes a taxpayer as a single company, and the holding entities are treated as plants of the company. All operations conducted by holding entities are included directly in the holding account. Turnover between the companies does not have tax consequences for these companies; it is considered a so-called internal turnover. Receivables and payables arising between the holding companies as independent legal entities have, from a fiscal point of view, a neutral character. Tax should be applied only to the total profit of the holding as economic unity, determined on the basis of the tax balance sheet of the holding. In this case, a tax subject is not the parent company, but the holding is treated as a single company. The holding tax balance is created like the balance of a single company in which the holding entities are in the same position as the plants. This concept is the best solution to the problem of taxation of holding companies because the emphasis lies not in artificial legal creations but in the entire business, which is also the subject of taxation (Dischinger \& Riedel, 2010).

The concept of unity is characterised by the avoidance of multiple taxation of dividends, the elimination of taxation of unrealised profits in the holding company and merging financial results for tax purposes. The income (and losses) from taxation of the holding is not established on the basis of the trade consolidated balance. Tax law does not make use of the balance sheet regulations on that issue and creates its own regulations (Betten, 1987).

Another group consists of countries whose regulations related to the taxation of holding companies are based on the theory of separation. This group includes Belgium, Greece and Italy. Their holdings cannot count on special taxation preferences, except for construction, which allows them to avoid the multiple taxation of dividends. Holdings using this theory are taxed as separate taxable entities despite the fact that from an economic point of view, they are seen as unity. In this theory, holding companies are legal persons, but the holding as such has no legal personality and is denied taxation subjectivity. Despite the existing relationship of subordination of the holding company and a uniform board, the holding company's profits for tax purposes are determined in accordance with the theory of separation, as though the company was an independent entity not only in legal terms but also on an economic basis. The theory of tax revenue applies to these holdings, according to which income can be attributed only to individual or legal persons, not to an entity established solely on the basis of economic criteria (Scheuchzer, 1994).

In the economic operations between companies of a holding company that uses the theory of separation, internal billing rates can be used, which are different from the market prices for identical transactions by independent businesses. The taxation basis means a shift in the profits and losses accepted for tax purposes between these companies. Creating the taxation fiction for tax authorities that the holding companies are economically independent entities poses a difficult task that consists of price control between holding companies to determine whether these prices actually correspond to the prices that, in the same or similar conditions, were agreed upon between independent entities. In case of a negative result of this control for the holding companies, the tax authorities make an appropriate adjustment of prices and ascribe to these companies the profits they would gain as independent entities (Hong \& Smart, 2010).

It must be clearly stated that the theory of separation can lead to a correction of the holding companies' incomes and losses for tax purposes to limit the economic connections between them while completely ignoring the financial results of the holding company as a whole.

The third group includes countries that combine the theory of economic unity with the theory of separation, commonly known as the mixed theory (Germany, Denmark, Luxembourg and Poland). These countries have regulations preventing multiple taxation of dividends and merging financial results for tax purposes. They lack the possibility of eliminating the taxation of unearned incomes within the holding company (Salzberger, 1994).

In most countries, the tax income of the holding does not include the income gained from foreign 

dividends is a resident of a different country than the company or companies paying dividends. The problem of multiple taxation of dividends is completely eliminated if the holding company is taxed by applying the theory of unity. The dividends transferred between the companies of a holding are treated as if certain components of the profit were moved between plants of the same company. Therefore, they represent an internal transfer of the capital and, from a tax point of view, are completely neutral (Salzberger, 1994).

For tax purposes, merging the financial results of subsidiaries of a holding to tax the consolidated financial results is significant, especially from the point of view of the covering losses of companies. When using the theory of separation, the holding company may cover its loss incurred in a particular tax year with income that will be obtained in the next years (losses transferred forward) or, if legally possible, with income gained in previous tax years (losses transferred backward). This is interperiodical covering of losses. However, there is no possibility of interpersonal covering of losses between independent legal entities (Dolton \& Saunders, 1995). In a situation in which some part of the holding company gains income while the holding company as a whole suffers a loss, the income of a holding is taxed that, on balance, has not appeared at all. Only when covering the losses of one holding company with the income of others, as postulated by the theory of unity, the income achieved by the holding company as a whole is taxable (Scheuchzer, 1994).

\section{Eliminating the taxation of unearned incomes within the holding company}

According to the theory of separation, sales between the entities of a holding mean the realisation of profits by the entity that makes the sale. The profit is subject to taxation. From the perspective of a holding company as a whole, there is no profit; there was a profit in the company as the result of transfer of certain assets between its entities. Treating sales between holding companies as sales between independent companies leads to a situation in which, from the perspective of the holding company as a whole, taxable income in some years is fictitiously overestimated (a holding company making sales to another holding company achieves income), whereas in other years it is fictitiously underestimated (a holding company purchasing a fixed asset from another holding company obtains depreciation from the purchase price). From the perspective of a holding company as a whole, profit is realised only when the commodity comes out of circulation within the holding. This result occurs when using the theory of unity, according to which circulation within the holding company has a neutral character from a taxation perspective (Scheuchzer, 1994).

\section{Summary}

In the majority of European Union countries, the institution of holding has become a frequently used form to optimise taxation. Holding companies planning their locations ignore EU countries, which lack tax-beneficial solutions. Therefore, countries using the theory of separation try to attract holdings with other tax benefits and locate them in their territories.

In the era of globalisation, capital companies use the institution of holding to shape their tax policy. Tax optimisation allows them to achieve large savings during the fiscal year, which constitute significant value in the context of all revenues. This is one of the most important arguments in favour of merging holding structures.

According to Clausing (2007), highly developed countries, such as the OECD and the EU, frequently create tax solutions favourable for corporations. These countries have no choice because the areas of tax havens present serious competition for them.

As emphasised by Devereux, Lackwood and Redo (2008), the harmonisation of policies on income tax of legal persons may be particularly useful during the current global crisis. Tax revenues resulting from the activity of holdings represent a significant part in the budgets of EU countries.

Tax regulations concerning holding companies are likely to be reformed to unify these rules. Current rules concerning the taxation of holding companies in different countries are so diverse that companies interested in this matter do not consider whether it is worthwhile to use these solutions but rather consider in which country to locate the parent company. It seems that the most appropriate way of implementing reforms will be to sanction holding tax law in EU community law.

Another consideration is whether a holding should obtain legal subjectivity, which will make it subject to rights and obligations, including tax liability. It should 
be remembered that the main objective of establishing a holding is to optimise the taxation of its entities.

\section{References}

Andersen, P. (2000). Denmark. In J. Van Hoorn \& J. Moore (Eds.) Guides to European taxation. Vol. 2: Taxation of companies in Europe (p. 169). Amsterdam: IBFD.

Becker, J., \& Fuest, C. (2011). Optimal Tax policy when firms are internationally mobile. International Tax and Public Finance, 18(5), 580-604.

Bestmann, U. (Ed.). (2001). Kompendium der Betriebswirtschaftslehre [Compendium of Business Administration] (10th ed.), München: Oldenbourg Wissenschaftsverlag.

Betten, R. (1987). The Fiscal Unity, International Aspects and Recent Developments, European Taxation, 3, 48.

Boekhorst, P. J. (2000). Netherlands. In J. Van Hoorn \& J. Moore (Eds.), Guides to European taxation. Vol. 2: Taxation of companies in Europe (p. 125). Amsterdam: IBFD

Bouzidi, B., \& Bouzora, M. (2000). France. In J. Van Hoorn \& J. Moore (Eds.), Guides to European taxation. Vol. 2: Taxation of companies in Europe (p. 189). Amsterdam: IBFD

Büchner, R. (1990). Reaktionen des Aktienmarktes auf Unternehmenszusammenschlüsse - Eine empirische untersuchung [Reactions of the stock market on business combinations - An empirical study], Zeitschrift für betriebswirtschaftliche Forschung, 4(4), 295-317

Clausing, K. (2007). Corporate Tax Revenues in OECD Comtries, International Tax and Public Finance, $14,115-133$.

Devereux, M.P., Lockwood, B., \& Redoano, M. (2008). Do Comitries Compate Over Corporate Tax Vates, Journal of Public Economics, 92(5-6), 1210-1235.

Dischinger, M., \& Riedel, N. (2010). Corporate Taxes and the location of intangible assets within multinational firms, Journal of Public Economics, 95(7-8), 691-707.

Dolton, A., \& Saunders, G. (1995). Tolley's Corporation Tax. London: Tolley Publishing Co LTD..

Egger, P., \& Merlo, V. (2011). Statutory Corporate Tax Rates and Double-Taxation Treaties as Determinants of Multinational Firm Actuvity, FinanzArchiv, 67(2), 145-170.
Froud, J., Haslam, C., Johal, S., \& Williams, K. (2000). Shareholder Value and Financialization Consultancy Promises, Management Moves, Economy and Society, 29, 1255-1271.

Grotherr, S. (1995). Die konsolidierte Konzernbesteuerung von spanischen Aktiengesellschaften [The consolidated group taxation of Spanish corporations], Internationales Steuerrecht, 1, 18, 16-24.

Hong, Q., \& Smart., M. (2010). In praise of tax havens: International tax planning and foreign direct investment, European Economic Review, 54(1), 82-95.

Haus, B., Jagoda, H., \& Karaś, M. (1993). Establishment and Running of Holding Companies. Wroclaw: WSB,

IBFD. (2000). European Tax Handbook. London: United Kingdom-Taxation of Corporations.

Jaeger, H. K. (1984). The Structure of Consolidated Accounting. London: Dellen Publishing Company.

Karolak, A. (2001). Legal Basis for the Creation and Running of Holding, Overview of Economic Legislation, 5, 36-41.

Kay, J.A., \& King, M.A. (1990). The British Tax System. Oxford: Clarendon Press.

Kessler, W. (1996). Die Euro-Holding. München: C.H. Beck.

Knoepfler, P., \& Anderson, J. (1988). Towards a Real Tax Group Harmonization, European Taxation, 3 , 172-178.

Kohler, E. L. (1938). Some Tentative Propositions Underluing Consolidated Reports, The Accounting Review, 13(1), 38-44.

Kubot, Z. (1993). Struktury holdingowe [Holding structure]. Zielona Gora: Regional Development Agency.

Kütting, K. (1980). Zur Systematiesierung von Konzernstrukturen, Wirtschaftswissenschaftliches Studium, 9 (1), 6-10

Laconick, W., \& O'Sullivan, M. (2000). Maximizing Shareholder Value: A New Ideology for Corporate Governance, Economy and Society, 29, 978-992.

Lichtarski, J. (1992). Teoretyczne i praktyczne problemy integracji przedsiębiorstw [Theoretical and practical problems of enterprise integration]. In Lichtarski J. (Ed.), Współdziałanie gospodacze przedsiębiorstw [Economic Cooperation of Companies]. Warsaw: PWE

Lutter, M. (1995). Holding Handbuch. Köln: C. H. Beck. 
Melcon, A. (1989). Analisis contable del regimen de declariacion consolidada de los grupos de sociedades. Madrid: Editorial AC.

Niels, J. (2010). Imperfect tax competition for profits, asymmetric equilibrium and beneficial tax havens, Journal of International Economics, 81(2), 253-264.

Nobes, C. (1987). Some Practical and Theoretical Problems of Group Accounting. London: Certified Accountant Publication.

Nogalski, B., \& Ronkowski, R. (1994). Holding czyli o instytucji szczególnie efektywnej w pewnych sytuacjach [About holding - an increase of institutions particularly effective in certain situations]. Warsaw: ORGMASZ.

Opalski, A. (1997). Koncern w niemieckim prawie spółek [Concern in German company law], Przegląd Prawa Handlowego, 2, 40-49.

Ordelheide, D. (1986). Konzern und Konzernerfolg, [Corporate and consolidated income] Wirtschaftswissenschaftliches Studium, 2, 495-502

Overesch, M., \& Wamser, G. (2010). Corporate Tax planning and thin-capitalization rules: evidence from a quasi experiment, Applied Economics, 42(5), 563-573.

Palpaceur, F. (2008). Bringing the Social Contex Bach In: Governance and Wealth Distribution in Global Commodity Chains, Economy and Society, 37(3), 1118-1134.

Poterba, J.M. (2004). Taxation and Corporate Payout Policy, American Economic Review, 94, 541-559.

Salzberger, W. (1994). Die steuerliche Gewinnemittlung einer Konzernunternehmung in der Europäischen Union [Determining taxable income of a Corporate company in the European Union], Köln: C.H. Beck.

Scheuchzer, M. (1994). Konzernbesteuerung in der Europäischen Union [Corporate taxation in the European Union], Bielefeld: C.H. Beck.

Schmidt, K. (1997). Gesellschaftsrecht [Company law], (4th ed.). Köln: Alpmann Schmidt. .

Solarz, J. K. (1992). Holding finansowy [Financial Holding]. Warsaw: PWE.

Stecki, L. (1999). Holding [Holding]. Torun: TNOiK.

Stecki, L. (2001). Koncern [Concern]. Torun: TNOiK.

Strobel, A. (1995). Consolidation under Danish Law,

Tax Planning International Review, 9, 27-33.
Szumański, A. (2001). Ograniczona regulacja prawa holdingowego (prawa grup spółek) wkodeksie spółek handlowych [Limited regulation of holding company law (law of groups of companies) in the Commercial Companies Code]. Państwo $i$ Prawo, 3, 20-29.

Szumański, A. (1996). Regulacja prawna holdingu w polskimi europejskim prawie spółek (zagadnienia pojęciowe) [Legal regulation of the holding in the Polish and European company law (conceptual issues)]. Przeglad Prawa Handlowego, 8, 39-48.

Te Spenke, G., \& Lier, P. (1992). Taxation in the Netherlands. Deventer: Kluwer Law and Taxation Publishers.

Warchoł, J. (2001). Umowy koncernowe w prawie niemieckim i polskim. Wzory umów [Contract law concerns in German and Polish. Model contracts]. Krakow: Ostoja.

Wöhe, G. (1978). Einführung in die allgemeine Betriebwirtschaftlehre [Introduction to general business administration]. München: n.d.

Wakkie, P., \& Meer, T. (1992). Mergers and Acquisitions in the Netherlands, Legal and Tax Aspects. Deventer: Kluwer Law and Taxation.

Vlachy, J. (2008). Investigating a Thin-Capitalization Rule: an option-based analysis, Politicka Ekonomie, 56(5), 656-668.

Yamauchi, K. (1992). Konzernrecht in Japan [Corporate Law in Japan], Zeitschrift für Unternehmens und Gesselschaftsrecht, 1, 28-34. 